\title{
Evaluation of Mechanical Parameters of Bacterial Concrete
}

\author{
Chereddy Sonali Sri Durga*, Nerella Ruben, Madduru Sri Rama Chand, Chava Venkatesh
}

Department of Civil Engineering, Vignan's Foundation for Science, Technology \& Research, Deemed to be University, Guntur, Pin-522211, Andhra Pradesh, India

Corresponding Author Email: chssd_civilp@vignan.ac.in

https://doi.org/10.18280/acsm.430606

Received: 25 July 2019

Accepted: 1 October 2019

\section{Keywords:}

biological agents, cracks, healing, impervious, mechanical properties

\begin{abstract}
Conventional concrete is prone to cracking under tensile load, despite its good compressive strength. Recently, biological agents have been applied to heal the cracks in concrete, making concrete structures more serviceable. This paper mainly attempts to evaluate the mechanical properties of bacteria-based self-healing concrete. Two bacteria were selected as the bioagents in concrete, namely, Bacillus subtilis and Bacillus halodurans. The concentration of the bioagents were set to $10^{5} \sim 10^{7}$ cell $/ \mathrm{mL}$ in water. Then, the two bacteria were applied to cracked concrete to cure the cracks. After curing for several days, the bacteria-based self-healing concrete was subjected to compressive and flexural tests to estimate its mechanical parameters. The results show that the self-healing concretes cured for $14 \mathrm{~d}$ and $28 \mathrm{~d}$ had a $7 \%$ and $18 \%$ higher compressive strength than conventional concrete, respectively; the self-healing concretes cured for $14 \mathrm{~d}$ and $28 \mathrm{~d}$ had a $11 \%$ and $28 \%$ higher flexural strength than the conventional concrete, respectively. Thus, the bioagents could effectively heal the surface cracks on concrete, and make the concrete imperviable.
\end{abstract}

\section{INTRODUCTION}

A lot of severe issues like shortage of resources, consumption of energy and emissions of carbon dioxide are challenging today's construction industry. Concrete is a major structural element used for construction of small to heavy building units around globe. The utilization of concrete is more in construction because of its high compressive strength and ability to form into desired shapes. Due to limited tensile strength of concrete, cracks are formed internally and externally. Reinforcement of steel has become a solution for increasing tensile strength, but it doesn't arrest the cracks completely [1].

The demand for new constructions has to be decreased by prolonging the service life of existing structure. In addition to that, the repair and maintenance costs due to premature failure of structures have to be decreased. All the above parameters can be possible only by arresting the formation of crack and crack widening. Although a lot of precautions are taken, cracks are formed due to unskilled labour, human errors and climatic conditions. Development of crack is not a problem; its enlargement endangers the concrete structure. If left neglected, affects the performance of concrete. The factors which are responsible for evolution and propagation of cracks are uneven settlement, poor design, contraction and repeated application of loads [2].

The disintegration of concrete due to cracking is one of the major culprits endangering the durability, safety and integrity of concrete structures [3]. The crack was formed in the concrete in the initial stages due to heat released in the hydration process. To avoid these cracks, sprinkling of water and spreading of wet hessian clothes were done to provide a constant climate on the surface [4]. Corrosion of reinforcement is an important parameter results in deterioration of concrete structures. The protection was given to reinforcement by the formation of passive film on its surface; destruction of this passive film promotes corrosion due to ingress of chlorides and gases in the cracks of concrete. [5]. For the underground structures and bridges, crack treatment is very difficult, time consuming and labour expensive.

The cracks formed in concrete let the chlorides and gases contact with reinforcement, starts the corrosion process affecting the strength of concrete structure. The parameters such as strength, impermeability and durability of concrete structure decreases by the crack formation [6]. There is a need to address durability of a concrete structure to expand the service life [7]. Repair of cracks is possible, but it is very expensive and difficult to repair cracks that can't be seen [8]. Large amount of cement is necessary for repair and rebuilt of structural damage, increasing the generation of cement raises hazardous emissions to atmosphere [9]. A lot of economic pressure has developed by structure degradation. This phenomenon of decrease in cracks has to resolve by attaining sustainable development [10].

The idea of self healing has come from the biological systems, as many plants and animals having the ability to recover from serious damage to a full extent. This thought has applied to many engineering problems [11]. The property of self heal is not only in cement concrete but also in asphalt concrete which is used in road constructions. The performance of pavement was affected directly by the cracks in the asphalt concrete. The flow ability of asphalt can fill the micro cracks improving the structural performance and extending the service life of roads [12]. Engineering cementitious composites are one of high performance fiber reinforced cementitious composites used to conceal crack propagation and further increase in width of cracks [13]. 
The healing of cracks in concrete can be done biologically by self healing concrete. The bacteria which are used as self healing agent has the capability to absorb oxygen present internally in the concrete inhibit the corrosion process. The ways for sealing cracks can be done by formation of CSH gel and calcite crystals, hydration of unreacted cement grains [14]. The formation of calcium carbonate is shown in Eq. (1).

$$
\mathrm{CaO}+\mathrm{CO} 2 \rightarrow \mathrm{CaCO} 3
$$

The performance of healing cracks can be enhanced by various parameters viz: biological agents [15-21], chemical agents [22], encapsulated capsules [23-27] and pozolonic materials [28]. There is an improvement in lifetime of concrete structure by crack healing. Many researchers were doing their work for sustainable development [29-32]. This paper discusses about the growth and shape of bacteria. The growth pattern of bacteria in concrete composition was tested. The mechanical parameters of concrete like compressive strength and flexural strength are computed of various cell concentrations of bacteria.

\section{MATERIALS}

Ordinary Portland cement of grade 53 is used and all the properties of cement are as per the IS 269-2015 in the present work [33]. The chemical composition of cement was enlisted in Table 1. The river sand satisfying Zone II is termed as fine aggregate in the guidelines of IS 383-2016 [34]. The crushed granite stones of $20 \mathrm{~mm}$ size are in use of coarse aggregate and all the properties are within the limits of IS 2386-1963 [35]. The water used in the concrete are confirming the requirements of IS 456-2000 [36]. The physical properties of cement, coarse and fine aggregate are shown in Table 2.

Table 1. Chemical composition of cement

\begin{tabular}{cc}
\hline Compounds & Weight (\%) \\
\hline $\mathrm{CaO}$ & 63.29 \\
$\mathrm{SiO}$ & 20.93 \\
$\mathrm{Al}_{2} \mathrm{O}_{3}$ & 4.73 \\
$\mathrm{Fe}_{2} \mathrm{O}_{3}$ & 3.95 \\
$\mathrm{TiO}_{2}$ & 2.49 \\
$\mathrm{Na}_{2} \mathrm{O}$ & 0.22 \\
$\mathrm{MgO}$ & 0.45 \\
Others & 3.94 \\
\hline
\end{tabular}

Table 2. Physical properties of cement, coarse aggregate and fine aggregate

\begin{tabular}{cc}
\hline Material properties & Values \\
\hline Specific gravity of cement & 2.98 \\
Fineness of cement & $9 \mathrm{gms}$ \\
Stamdard Consistency of cement & $34 \%$ \\
Initial setting time of cement & $40 \mathrm{~min}$ \\
Final setting time of cement & $420 \mathrm{~min}$ \\
Specific gravity of coarse aggregate & 2.82 \\
Fineness modulus of coarse aggregate & 7.14 \\
Specific gravity of fine aggregate & 2.64 \\
Fineness modulus of fine aggregate & 3.09 \\
\hline
\end{tabular}

\subsection{Bacteria cultivation}

An ureolytic type bacterium of bacillus subtilis and bacillus halodurans with different cell concentrations are used in the present work. The nutrient broth medium was used for culturing bacteria. The broth solution consists of 100 $\mathrm{ml}$ of distilled water dissolved with $0.3 \mathrm{gms}$ of beef extract, $0.5 \mathrm{gms}$ of peptone and $0.5 \mathrm{gms}$ of sodium chloride and sterilized for $20 \mathrm{~min}$ at a temperature of $121{ }^{\circ} \mathrm{C}$. Allow it to cool, then the cultured was inoculated into medium and incubated at $37^{\circ} \mathrm{C}$ temperature in an incubated shaker at a speed of $85 \mathrm{rpm}$ for $24 \mathrm{hrs}$. Gram staining process was done to determine the shape of bacteria. All the images were taken using microscope. The growth pattern of bacteria was checked in the concrete composition medium. By using UV Spectrophotometer, the growth pattern was observed with respect to time.

\section{MIX PROPORTIONS AND SPECIMENS PREPARATIONS}

The concrete specimens are prepared using M40 grade concrete for both control and bacterial concrete specimens as per IS 10262-2019 [37]. The mix calculations of concrete are shown in Table 3.

Table 3. Mix calculations of concrete specimens

\begin{tabular}{ccc}
\hline S.No & Materials & Units $\left(\mathbf{k g} / \mathbf{m}^{\mathbf{3}}\right)$ \\
\hline 1. & OPC & 420 \\
2. & FA & 613.934 \\
3. & CA & 1119.615 \\
4. & Water & 186 \\
\hline
\end{tabular}

Table 4. Mixes of concrete

\begin{tabular}{|c|c|c|c|}
\hline S.No & Mix Id & Bacteria type & $\begin{array}{c}\text { Cell } \\
\text { concentration }\end{array}$ \\
\hline 1. & Control Mix & - & - \\
\hline 2. & $\begin{array}{c}\text { Bacillus } \\
\text { subtilis }\left(10^{5}\right)\end{array}$ & Bacillus subtilis & $10^{5}$ \\
\hline 3. & $\begin{array}{c}\text { Bacillus } \\
\text { subtilis }\left(10^{6}\right)\end{array}$ & Bacillus subtilis & $10^{6}$ \\
\hline 4. & $\begin{array}{c}\text { Bacillus } \\
\text { subtilis }\left(10^{7}\right)\end{array}$ & Bacillus subtilis & $10^{7}$ \\
\hline 5. & $\begin{array}{c}\text { Bacillus } \\
\text { halodurans } \\
\left(10^{5}\right)\end{array}$ & $\begin{array}{c}\text { Bacillus } \\
\text { halodurans }\end{array}$ & $10^{5}$ \\
\hline 7. & $\begin{array}{c}\text { Bacillus } \\
\text { halodurans } \\
\left(10^{6}\right)\end{array}$ & $\begin{array}{c}\text { Bacillus } \\
\text { halodurans } \\
\text { Bacillus } \\
\text { halodurans } \\
\left(10^{7}\right)\end{array}$ & $\begin{array}{c}\text { Bacillus } \\
\text { halodurans }\end{array}$ \\
\hline
\end{tabular}

The bacterial samples are prepared using bacillus subtilis and bacillus halodurans with cell concentration of $10^{5} \mathrm{cell} / \mathrm{ml}$ to $10^{7} \mathrm{cell} / \mathrm{ml}$ of water. Normal water was used for curing the concrete samples as per IS 9013-1978 [38]. The mechanical parameters are estimated by casting the specimens in various shapes of moulds. The concrete mixes were prepared and poured in the framework arragment of moulds which were coated with oil. For proper distribution of concrete uniformly in the moulds the compaction was done using tamping rod with 25 strokes. After $24 \mathrm{hrs}$, the concrete samples are taken out from the framework of moulds and placed in the curing tank for 14 and 28 days. For reporting the test resuts, average of five samples are taken. The mechanical properties of concrete are assessed by cast and testing the cubical 
specimens with size $150 \times 150 \times 150 \mathrm{~mm}$ of 70 numbers for compressive strength test and beam specimens with size $100 \times 100 \times 500 \mathrm{~mm}$ of 70 numbers for flexural strength test. The mixes of concrete samples are shown in Table 4.

\section{EXPERIMENTAL PROGRAM}

\subsection{Compressive strength test}

The Compressive strength test was done for the concrete samples hardenened due to curing process. The size of specimens adopted is $150 \mathrm{~mm} \times 150 \mathrm{~mm} \times 150 \mathrm{~mm}$. As per the code IS: 516-2013 the test was done for both normal and bacterial concrete samples. The capacity of compression testing machine is $2000 \mathrm{KN}$ and samples are tested with a loading rate of $140 \mathrm{~kg} / \mathrm{cm}^{2} / \mathrm{min}$. The compressive strength can be obtained by calculating the ratio of compressive load with cross-sectional area. The testing pattern of compressive strength is shown in Figure 1.

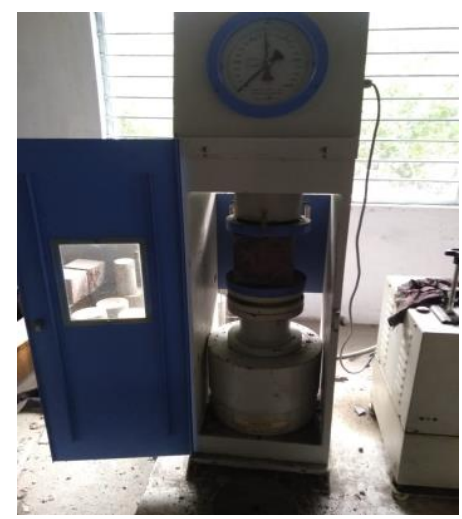

Figure 1. Compressive strength test of concrete specimen

\subsection{Flexural strength test}

The Flexural strength test has done for two point loading as per the code IS: $516-1959$ for the specimens of size 100 $\mathrm{mm} \times 100 \mathrm{~mm} \times 500 \mathrm{~mm}$ (length $\times$ width $\times$ depth). It measures the capability of beam or slab to withstand failure in bending. The results of flexural strength test are in terms of modulus of rupture. The samples are tested with a loading rate of 140 $\mathrm{kg} / \mathrm{cm}^{2} / \mathrm{min}$ and capability of flexural testing machine is 100 $\mathrm{KN}$. The flexural strength can be calculated by using the formulae represented in Eq. (2). The testing pattern of compressive strength is shown in Figure 2.

$$
f_{b}=\frac{3 P L}{2 b d^{2}}
$$

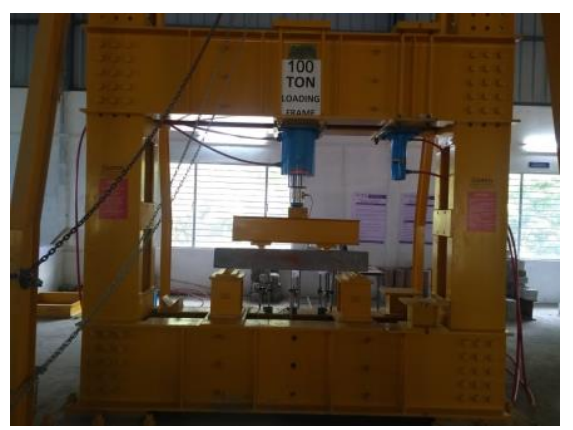

Figure 2. Flexural strength test of concrete specimen

\section{ANALYSIS OF RESULTS}

The self healing products are quantified and characterized by mechanical parameters of concrete via compressive strength and flexural strength.

\subsection{Compressive strength}

The specimens were cast of size $150 \mathrm{~mm} \times 150 \mathrm{~mm} \times 150$ $\mathrm{mm}$ for control and bacterial mixes and compressive strength test was done as per IS 516-2013 [39]. The strength was calculated for 14 and 28 days of curing after cracking. Bacillus halodurans with a concentration of $10^{5}$ cells $/ \mathrm{ml}$ of water shows more healing compared to other mixes by formation of calcite crystals. There is a rise in compressive strength of 51.67 Mpa for 14 days and 62.15 Mpa for 28 days of curing compared to control mix samples. The results of compressive strength are shown in Figure 3 and Figure 4.

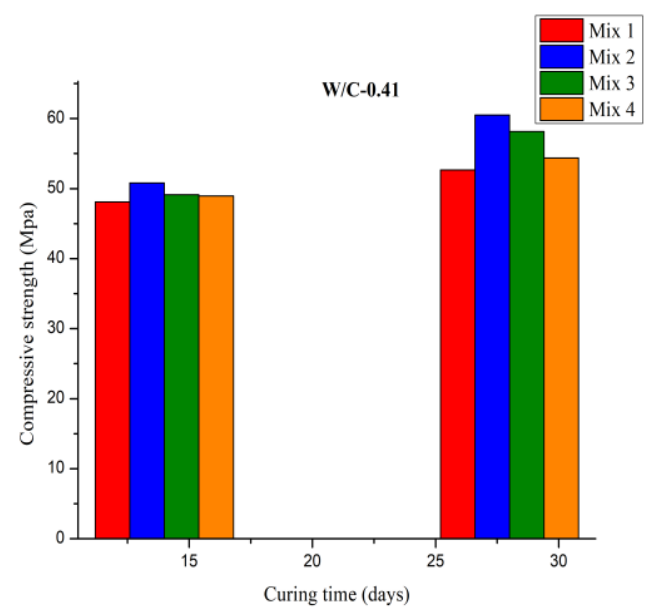

Figure 3. Compressive strength of concrete for various cell concentration of bacillus subtilis

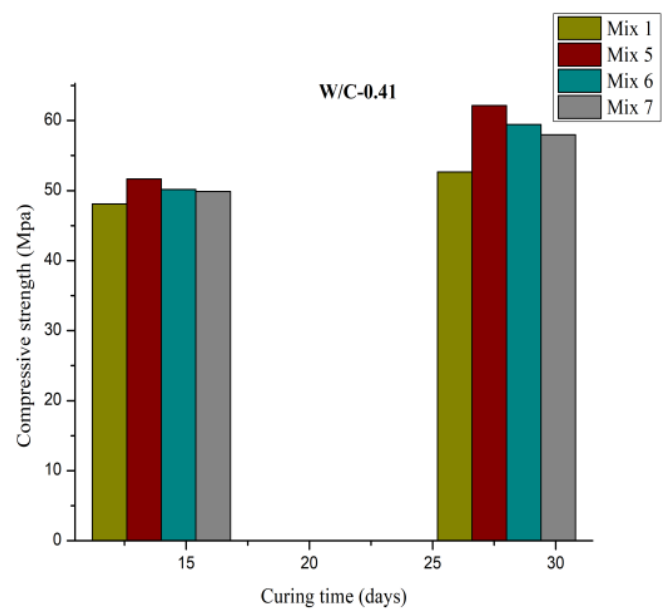

Figure 4. Compressive strength of concrete for various cell concentration of bacillus halodurans

\subsection{Flexural strength}

The samples of size $500 \mathrm{~mm} \times 100 \mathrm{~mm} \times 100 \mathrm{~mm}$ was cast of ordinary and bio concrete mixes and are tested for flexural strength with two point loading as per IS 516-1959 [40]. The assessment of strength was done for 14 and 28 days of curing after cracking. There is a raise in flexural strength of 4.86 
Mpa for 14 days and 5.64 Mpa for 28 days of curing compared to ordinary concrete specimens after cracking. The more healing rate is shown by bacillus halodurans with a concentration of $10^{5}$ cells $/ \mathrm{ml}$ of water due to EPS layer formation of bacterial strain. The results of flexural strength are shown in Figure 5 and Figure 6.

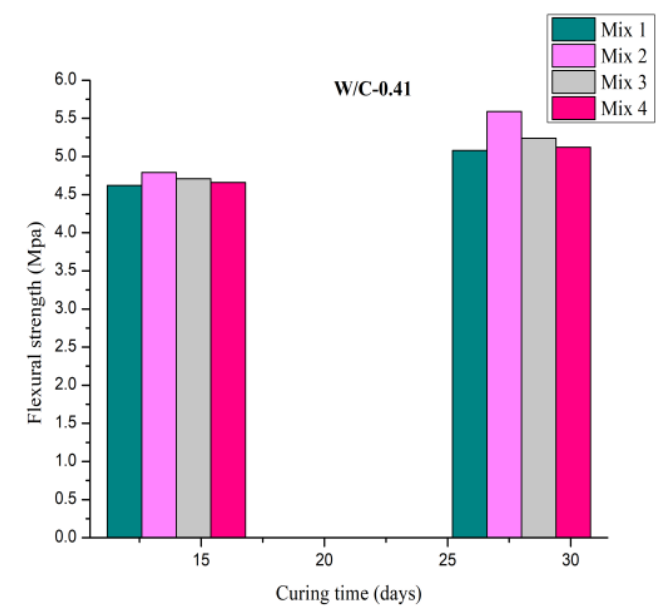

Figure 5. Flexural strength of concrete for various cell concentration of bacillus subtilis

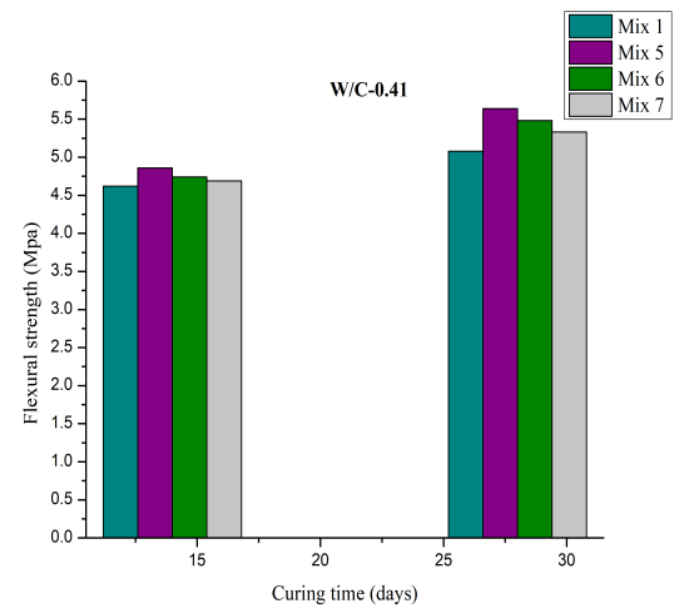

Figure 6. Flexural strength of concrete for various cell concentration of bacillus halodurans

\section{CONCLUSIONS}

This paper discusses about the behaviour of biological agents to heal the cracks on concrete surface. Gram staining process give the results that both bacillus subtilis and bacillus halodurans are rod shaped ones. The growth pattern of bacillus halodurans is more compared to bacillus subtilis in the concrete composition medium through microbiological activity. The performance of bacteria in concrete in terms of mechanical characteristics with respect to compressive strength and flexural strength are computed. There is a regain of compressive strength of concrete due to calcite crystal formation by bacteria. The flexural strength of concrete increases by EPS layer formation of bacterial strain. The specimens cast using bacillus halodurans with concentration of $10^{5}$ cells $/ \mathrm{ml}$ of water shows more recovery in both compressive and flexural strengths with respect to conventional concrete due to formation of calcium carbonate.
Further studies have to be done on the durability properties of concrete. The rate of healing by using various self-healing agents has to be computed.

\section{REFERENCES}

[1] Insaurralde, C.C., Rahman, P.K.S.M., Ramegowda, M., Vemury, C.M. (2016). Follow-up methods for autonomic repairing process. IEEE International Conference on Systems, Man and Cybernetics (SMC). https://doi.org/10.1109/smc.2016.7844997

[2] Suryanto, B., Wilson, S.A., McCarter, W.J., Chrisp, T.M. (2015). Self-healing performance of engineered cementitious composites under natural environmental exposure. Advances in Cement Research, 28(4): 1-10. https://doi.org/10.1680/adcr.15.00022

[3] Li, W.T., Dong, B.Q., Yang, Z.X., Xu, J., Chen, Q., Li, H.X., Xing, F., Jiang, Z.W. (2018). Recent advances in intrinsic self-healing cementitious materials. Advanced Material Interfaces, 30(17). https://doi.org/10.1002/adma.201705679

[4] Frei, R., McWilliam, R., Derrick, B., Purvis, A., Tiwari, A., Serugendo, G.D.M. (2013). Self-healing and selfrepairing technologies. The International Journal of Advanced Manufacturing Technology, 69(5-8): 10331061. https://doi.org/10.1007/s00170-013-5070-2

[5] Dong, B.Q., Ding, W.J., Qin, S.F., Fang, G.H., Liu, Y.Q., Dong, P., Han, S.W., Xing F., Hong, S.X. (2018). $3 \mathrm{D}$ visualized tracing of rebar corrosion-inhibiting features in concrete with a novel chemical self-healing system. Construction and Building Materials, 168: 1120. https://doi.org/10.1016/j.conbuildmat.2018.02.094

[6] Luhar, S., Gourav, S. (2015). A review paper on self healing concrete. Journal of Civil Engineering Research, 5(3): 53-58. https://doi.org/10.5923/j.jce.20150503.01

[7] Joseph, C., Jefferson, A., Isaacs, B., Lark, R., Gardner, D. (2010). Experimental investigation of adhesivebased self-healing of cementitious materials. Magazine of Concrete Research, 62(11): 831-843. https://doi.org/10. 1680/ macr.2010.62.11.831

[8] Pérez, G., Calvo, J.L., Carballosa, P., Tian, R., Allegro, V.R., Erkizia, E., Guerrero, A. (2017). Durability of self-healing ultra-high-strength reinforced microconcrete under freeze-thaw or chloride attack. Magazine of Concrete Research, 69(23): 1231-1242. https://doi.org/10.1680/jmacr.17.00075

[9] Seifan, M., Sarmah, A.K., Ebrahiminezhad, A., Ghasemi, Y., Samani, A.K., Berenjian, A. (2018). Bioreinforced self-healing concrete using magnetic iron oxide nanoparticles. Applied Microbiology and Biotechnology, 102(5): 2167-2178. https://doi.org/10.1007/s 00253-018-8782-2.

[10] Arce, G.A., Hassan, M.M., Mohammad, L.N., Rupnow, T. (2019). Self-healing of SMA and steel-reinforced mortar with microcapsules. Journal of Materials in Civil Engineering, $31(2)$. https://doi.org/10.1061/(asce)mt.1943-5533.0002568

[11] Ghodke, P., Mote, S. (2018). The self-healing concrete - A review. International Journal of Advances in Engineering \& Technology, 11(1): 29-34.

[12] Fan, S., Wang, H., Zhu, H., Sun, W. (2018). Evaluation of self-healing performance of asphalt concrete for lowtemperature fracture using semicircular bending test. 
Journal of Materials in Civil Engineering, 30(9).

[13] Yıldırım, G., Khiavi, A.H., Yeşilmen, S., Şahmaran, M. (2018). Self-healing performance of aged cementitious composites. Cement and Concrete Composites, 87: 172186. https://doi.org/10.1016/j.cemconcomp.2018.01.004

[14] Hung, C., Su, Y., Su, Y. (2018). Mechanical properties and self-healing evaluation of strain-hardening cementitious composites with high volumes of hybrid pozzolan materials. Composites Part B: Engineering, 133:

$15-25$. https://doi.org/10.1016/j.compositesb .2017.09.005

[15] Babu, N.G., Siddiraju, S. (2016). An experimental study on strength and fracture properties of self healing concrete. International Journal of Civil Engineering and Technology, 7(3): 398-406.

[16] Xu, J., Wang, X.Z. (2018). Self-healing of concrete cracks by use of bacteria-containing low alkali cementitious material. Construction and Building Materials, 167: 1-14. https://doi.org/10.1016/j.conbuildmat.2018.02.020

[17] Vashisht, R., Attri, S., Sharma, D., Shukla, A., Goel, G. (2018). Monitoring biocalcification potential of Lysinibacillus sp. isolated from alluvial soils for improved compressive strength of concrete. Microbiological Research, 207: 226-231. https://doi.org/10.10 16/j.micres.2017.12.010

[18] Singh, N., Ahmad, J., Mir, S.S. (2018). Assessment of ureolytic bacteria for self-healing concrete. International Journal of Recent Scientific Research, 9(3J): 2535025355. https://doi.org/10.24327/ ijrsr. 2018.0903.1943

[19] Xu, J., Wang, X.Z., Zuo, J., Liu, X. (2018). Self-healing of concrete cracks by ceramsite-loaded microorganisms. Advances in Materials Science and Engineering, 2018: 1-8. https://doi.org/10.1155/2018/5153041

[20] Durga, C.S.S., Ruben, N. (2018). A review of the mechanical behavior of substitution materials in selfhealing concrete. Lecture Notes in Civil Engineering. Sustainable Construction and Building Materials, 135144. https://doi.org/10.1007/978-981-13-3317-0_12

[21] Durga, C.S.S., Ruben, N., Chand, M.S.R., Venkatesh, C. (2019). Performance studies on rate of self healing in bio concrete. Materials Today: Proceedings. https://doi.org/10.1016/j.matpr.2019.09.151

[22] Ducasse-Lapeyrusse, J., Gagné, R., Lors, C., Damidot, D. (2017). Effect of calcium gluconate, calcium lactate, and urea on the kinetics of self-healing in mortars. Construction and Building Materials, 157: 489-497. https://doi.org/10.1016/j.conbuildmat.2017.09.115

[23] Araújo, M., Chatrabhuti, S., Gurdebeke, S., Alderete, N., Tittelboom, K.V., Raquez, J., Gruyaert, E. (2018). Poly (methyl methacrylate) capsules as an alternative to the proof-of-concept glass capsules used in self-healing concrete. Cement and Concrete Composites, 89: 260271. https://doi.org/10.1016/j.cemconcomp.2018.02.015

[24] Dong, B.Q., Ding, W.J., Qin, S.F., Han, N.X., Fang, G.H., Liu, Y.X., Hong, S.X. (2018). Chemical selfhealing system with novel microcapsules for corrosion inhibition of rebar in concrete. Cement and Concrete Composites, 85 :

83-91. https://doi.org/10.1016/j.cemconcomp.2017.09.012

[25] Heede, P.V., Belleghem, B.V., Araújo, M.A., Feiteira,
J., Belie, N.D. (2018). Screening of different encapsulated polymer-based healing agents for chloride exposed self-healing concrete using chloride migration tests. Key Engineering Materials, 761: 152-158. https://doi.org/10.4028/www.scientific.net/KEM.761.15 2

[26] Mauludin, L.M., Zhuang, X., Rabczuk, T. (2018). Computational modeling of fracture in encapsulationbased self-healing concrete using cohesive elements. Composite Structures, 196: 63-75. https://doi.org/10.1016 /j.comp struct. 2018.04.066

[27] Fang, G., Liu, Y., Qin, S., Ding, W., Zhang, J., Hong, S., Xing, F., Dong, B. (2018). Visualized tracing of crack self-healing features in cement/microcapsule system with X-ray microcomputed tomography. Construction and Building Materials, 179: 336-347. https://doi.org/10.1016/j.conbuildmat.2018. 05.193

[28] Durga, C., Ruben, N. (2019). Assessment of various self healing materials to enhance the durability of concrete structures. Annales De Chimie - Science Des Matériaux, 43(2): 75-79. https://doi.org/10.18280/acsm.430202

[29] Venkatesh, C., Chand, M., Nerella, R. (2019). A state of the art on red mud as a substitutional cementitious material. Annales De Chimie - Science Des Matériaux, 43(2): 99-106. https://doi.org/10.18280/ acsm.430206

[30] Venkatesh, C., Mohiddin, S.K., Ruben, N. (2018). Corrosion inhibitors behaviour on reinforced concrete A review. Lecture Notes in Civil Engineering. Sustainable Construction and Building Materials, 127134. https://doi.org/10.1007/978-981-13-3317-0_11

[31] Venkatesh, C., Ramanjaneyulu, V., Reddy, K., Durga, C., Sathish, P. (2019). A pilot strength studies on granite powder and silica fume based concrete. International Journal of Innovative Technology and Exploring Engineering, 8(7): 2278-3075.

[32] Sundari, K., Ramanjaneyulu, V., Praneetha, C., Venkatesh, C., Sathish, P. (2019). Influence of Br-Mk blend on micro structure, workability and mechanical properties of concrete. International Journal of Innovative Technology and Exploring Engineering, ISSN: 2278-3075, 8(8).

[33] IS:269-2015. (2015). Ordinary portland cementSpecification. Bureau of Indian Standards, New Delhi.

[34] IS:383-2016. (2016). Coarse and fine aggregate for concrete - specification. Bureau of Indian Standards, New Delhi.

[35] IS:2386-1963. (1963). Methods of test for aggregates for concrete. Bureau of Indian Standards, New Delhi.

[36] IS:456-2000. (2000). Plain and reinforced concrete code of practice. Bureau of Indian Standards, New Delhi.

[37] IS:10262-2019. (2019). Concrete mix proportioning guidelines. Bureau of Indian Standards, New Delhi.

[38] IS:9013-1978. (1978). Method of making, curing and determining compressive strength of accelerated-cured concrete test specimens. Bureau of Indian Standards, New Delhi.

[39] IS:516-2013. (2013). Methods of tests for strength of concrete. Bureau of Indian Standards, New Delhi.

[40] IS:516-1959. (1959). Methods of tests for strength of concrete. Bureau of Indian Standards, New Delhi. 